DOI 10.4467/2543733XSSB.20.001.12188

\title{
PROFESOR JERZY WYROZUMSKI (1930-2018) IN MEMORIAM
}

\author{
Professor Jerzy Wyrozumski (1930-2018) \\ In memoriam
}

Summary

Professor Jerzy Wyrozumski is one of the greatest Polish historians, researcher of the Middle Ages, Dean of the Faculty of History and Vice-Rector of the Jagiellonian University, an active member of the Polish Academy of Arts and Sciences and its Secretary General, President of the Society of History and Monuments Lovers of Krakow. He was awarded the title of doctor honoris causa by six universities for his scientific achievements, and decorated with many orders and medals (including the Commander's Cross of St. Sylvester, the Commander's Cross of the Order of Polonia Restituta, Officer's Cross of the Hungarian Order). Scholar with excellent achievements. Author of over 700 scientific papers, including a textbook of Polish history until 1505, the monumental first volume of the History of Krakow, the biography of Casimir the Great and Queen Hedwig of Anjou. An educator of many generations of historians, a Master for his students, a defender of the autonomy of the University and students in the 1980s.

W piątek 2 listopada 2018 r. zmarł w Krakowie Jerzy Lesław Wyrozumski, emerytowany profesor Uniwersytetu Jagiellońskiego, były dziekan Wydziału Filozoficzno-Historycznego i prorektor Almae Matris, członek czynny Polskiej Akademii Umiejętności, sekretarz generalny tejże Akademii, wieloletni prezes Towarzystwa Miłośników Historii i Zabytków Krakowa, doktor honoris causa sześciu uniwersytetów, jeden z najwybitniejszych polskich historyków.

Profesor urodził się w Trembowli w roku 1930 w rodzinie mieszczańskiej. Na chrzcie otrzymał imiona: Lesław, Grzegorz i Antoni. Natomiast imię Jerzy znalazło się omyłkowo na świadectwie szkolnym z Trembowli, gdzie rozpoczął szkolną edukację, którą przez krótki czas kontynuował we Lwowie. Gdy przy końcu wojny rodzina Wyrozumskich w pośpiechu opuszczała swoje rodzinne miasto, zabrano ze sobą najbardziej potrzebne 
dokumenty, w tym świadectwo szkolne. Po wojnie, podczas pobytu w Koźlu, wyrobiono przyszłemu profesorowi nowe dokumenty, a że jedynym świadectwem potwierdzającym imię było świadectwo szkolne z błędnie wypisanym przez nauczycielkę imieniem Jerzy, to takie imię sądownie otrzymał młody Wyrozumski. Mimo że wszyscy znali Profesora jako Jerzego Wyrozumskiego, to dla najbliższych przyjaciół był Leszkiem.

We wspomnianym Koźlu zdał maturę. W 1950 r. podjął studia historyczne na Uniwersytecie Jagiellońskim. Na seminarium profesora Romana Grodeckiego napisał pracę magisterską Handel solq $w$ Polsce $w$ wiekach średnich. Już wtedy dał się poznać jako świetny znawca łaciny, m.in. prowadził przez wiele lat zajęcia z łaciny średniowiecznej dla studentów historii, a w 1965 r. ogłosił nawet skrypt do ćwiczeń z łaciny średniowiecznej.

Po studiach Jerzy Wyrozumski pracował krótko w Archiwum Państwowym, a w marcu 1955 r. otrzymał asystenturę na Uniwersytecie Jagiellońskim. Pierwsze naukowe zainteresowania Profesora były związane $\mathrm{z}$ historią tkactwa, górnictwa, handlem solą oraz historią miast. Jako pracownik Katedry Historii Polski Feudalnej UJ, kierowanej przez profesora Romana Grodeckiego, zestawiał kartotekę materiałów do dziejów miast w Polsce. Wiązało się to nie tylko z przeszukiwaniem wydanego drukiem materiału źródłowego, ale również prowadzeniem kwerendy w różnych archiwach w Polsce w materiale rękopiśmiennym. Oprócz prowadzenia badań naukowych młody asystent wykonywał wiele obowiązków administracyjnych, m.in. protokołował posiedzenia Katedry. Protokoły te, zachowane do dzisiaj, stanowią nie tylko wspaniałe źródło do poznania ,życia codziennego" Katedry w trudnych latach pięćdziesiątych, ale też dowodzą niezwykłej akrybii przyszłego Profesora. Pośród pierwszych, jeszcze młodzieńczych prac Jerzego Wyrozumskiego spotykamy teksty o kongregacji włóczków krakowskich, warzelniach soli krakowskiej na pograniczu śląsko-polskim w drugiej połowie XVI i pierwszej połowie XVII wieku oraz biogramy pisane do Polskiego Słownika Biograficznego. Kilka prac poświęcił także Profesor zagadnieniom miejskim, czy to omawiając początki miast $\mathrm{w}$ regionie jasielskim, czy też pisząc krótkie syntezy dziejów Sławkowa i Tymbarku do jubileuszowej monografii miast polskich. W 1963 r. Jerzy Wyrozumski obronił pracę doktorską na temat tkactwa małopolskiego w późnym średniowieczu, która po różnych perypetiach ujrzała światło dzienne dopiero w 1972 r. Wcześniej, bo w 1968 r. Profesor habilitował się na podstawie rozprawy Państwowa gospodarka solna w Polsce do schytku XIV wieku.

Oprócz szeroko pojętej historii gospodarczej i społecznej ważnym polem naukowych dociekań Profesora była historia polityczna. W tym nurcie powstało szereg rozpraw i artykułów, na czele z biografiami Kazimierza Wielkiego i królowej Jadwigi Andegaweńskiej. Profesor Wyrozumski otrzymał też od noszącej imię ostatniego Piasta na polskim tronie Akademii Bydgoskiej doktorat honoris causa w 2005 r. Niewielka rozmiarami acz niezwykle ważna jest książka o królowej Jadwidze, bowiem znacząca jej część posłużyła jako materiał do opracowania Positio causa w procesie kanonizacyjnym królowej Jadwigi Andegaweńskiej. Wkład Profesora Wyrozumskiego w wyniesienie na ołtarze Andegawenki docenił sam papież Jan Paweł II, przyznając Mu Krzyż Komandorski św. Sylwestra, oraz Papieska Akademia Teologiczna, która uhonorowała Go medalem Bene merenti w 1998 r. Również dwa uniwersytety węgierskie, w Pécs i Miskolcu, nadały Mu doktoraty honoris causa. Podczas uroczystości w Pécs Profesor Wyrozumski swój wykład, będący zarazem podziękowaniem za nadany tytuł, przedstawił ... po łacinie. Prezydent Węgier w 2011 r. odznaczył Profesora Krzyżem Oficerskim Orderu Węgierskiego. 
Dzieje średniowiecznej kultury, w tym zwłaszcza pierwiosnki kultury humanistycznej oraz rola Uniwersytetu Krakowskiego i innych uniwersytetów europejskich, to kolejny bardzo płodny obszar zainteresowań badawczych Profesora. Dużo uwagi w swoim naukowym życiorysie poświęcał Profesor Wyrozumski dziejom Kościoła w Polsce średniowiecznej oraz hagiografii. W tym zakresie powstały ważne studia o arcybiskupach gnieźnieńskich XIII-XIV wieku, dziejach Kościoła krakowskiego w XIV wieku, o działalności świętych: św. Jacka, św. Wojciecha, św. Gereona, św. Stanisława.

Wielkim sukcesem, nie tylko wydawniczym, była Historia Polski do roku 1505, która ukazała się w ramach czterotomowego zarysu dziejów Polski, popularnie nazywana od trzech autorów trojaczkami krakowskimi (Jerzy Wyrozumski, Józef A. Gierowski i Józef Buszko). Służąca wielu rocznikom studentów historii doczekała się aż 13 wydań (I wydanie 1978). W 1999 r. poważnie rozszerzona część tej książki, obejmująca dzieje Polski piastowskiej, ukazała się jako drugi tom Wielkiej Historii Polski, opublikowanej przez Wydawnictwo Fogra. Równie wielką poczytność miała biografia Kazimierza Wielkiego pióra Profesora (dotychczas 3 wydania).

Jerzy Wyrozumski doprowadził do szczęśliwego końca reedycję Roczników Jana Długosza, które w pięknej szacie graficznej ukazały się zarówno po łacinie, jak i w tłumaczeniu na język polski. Równocześnie Profesor popularyzował wiedzę o największym polskim dziejopisie epoki średniowiecza i jego dziełach, np. poprzez wspieranie Ponadregionalnego Stowarzyszenia Edukacyjnego „Wieniawa” w Kłobucku, w którym Długosz był proboszczem.

Osobne miejsce w twórczości Profesora zajmowała problematyka miejska. Już w 1958 r. jako jeden ze swoich pierwszych artykułów opublikował tekst na temat kongregacji włóczków krakowskich. Potem Profesor brał udział jako współautor w opracowaniu kilku monografii miast, w tym m.in. Krosna, Dukli i Strzyżowa. W 1980 r. Jerzy Wyrozumski został wybrany na prezesa Towarzystwa Miłośników Historii i Zabytków Krakowa, którą to funkcję sprawował nieprzerwanie do 2015 r. W latach siedemdziesiątych XX wieku krakowskie Wydawnictwo Literackie powzięło zamiar wydania Dziejów Krakowa w kilku tomach. Pierwszy tom tej serii, zawierający średniowieczne dzieje Krakowa, miał wyjść spod pióra Józefa Mitkowskiego, profesora Uniwersytetu Jagiellońskiego. Był on bowiem najlepiej przygotowanym badaczem do napisania tego tomu. Niestety, śmierć Józefa Mitkowskiego w 1980 r. to zamierzenie zniweczyła. Napisanie średniowiecznych dziejów dawnej stolicy Polski przypadło w udziale Profesorowi Jerzemu Wyrozumskiemu. Efekt jego pracy okazał się imponujący. To wydany w 1992 r. (chociaż gotowy już w 1985 r.) opasły tom liczący 573 strony, a noszący tytuł Kraków do schyłku wieków średnich. Czytając jednakże jego dzieło, ma się wrażenie, że zostało napisane przez kogoś, kto nie tylko pokochał Kraków, ale też jakby się w nim urodził i wychował. W trzech zasadniczych, obszernych częściach zostały zaprezentowane dzieje Krakowa przedlokacyjnego, uformowanie się krakowskiego trójmiasta (w skład którego, oprócz Krakowa, wchodziły Kazimierz i Kleparz) oraz dzieje Krakowa u schyłku średniowiecza.

Problematyce dziejów Krakowa poświęcił Profesor wiele swoich prac, zwłaszcza przy okazji jubileuszu 750. rocznicy lokacji miasta na prawie niemieckim. Interesowała go szczególnie problematyka położenia centrum miasta przedlokacyjnego. Zdaniem Profesora owo centrum, czyli serce przedlokacyjnego Krakowa, znajdowało się na obszarze przylegającym do kościołów św. Trójcy, Wszystkich Świętych i Franciszkanów. Odrębnym 
nurtem tematycznym w badaniach Jerzego Wyrozumskiego nad średniowiecznym Krakowem jest życie gospodarcze średniowiecznego Krakowa i jego związki, głównie handlowe, $\mathrm{z}$ innymi miastami europejskimi. Wątek ten dominował w twórczości Profesora Wyrozumskiego u początków jego kariery badawczej. Nie porzucił go także w latach późniejszych, powracając od czasu do czasu do tych zagadnień. Średniowieczne cechy, związki czeladnicze i miejskie bractwa, które egzystowały w pejzażu średniowiecznego Krakowa, zostały scharakteryzowane przez Profesora w dwóch rozprawkach: Korporacje zawodowe i religijne w średniowiecznym Krakowie i Życie codzienne w średniowiecznym Krakowie. Dwa teksty, o związkach Krakowa ze Lwowem i z Norymberga, powstały na kanwie referatów konferencyjnych przygotowanych dla Międzynarodowego Centrum Kultury w Krakowie, w którym przez lata Profesor kierował Ośrodkiem Badań i sam zainicjował niegdyś cykl sympozjów historycznych. Kilka ważnych publikacji poświęcił Jerzy Wyrozumski dziejom Żydów krakowskich w średniowieczu.

Profesor Jerzy Wyrozumski, pełniąc liczne i odpowiedzialne funkcje, dał się poznać jako obrońca niezależności instytucji, którymi przyszło mu kierować. Gdy w 1980 r. został wybrany na prezesa Towarzystwa Miłośników Historii i Zabytków Krakowa zaangażował się mocno w obronę niezależności Towarzystwa, zwłaszcza w okresie stanu wojennego. Jako prorektor Uniwersytetu Jagiellońskiego w latach 1987-1990 bronił autonomii Uniwersytetu, potrafiąc całym sercem stanąc po stronie aresztowanych studentów. Pięknym dowodem na odwagę Profesora jest zdjęcie zrobione przez anonimowego fotografa przed budynkiem Collegium Novum, gdy Profesor z rozłożonymi rękami podejmuje dialog z grupą milicjantów, otaczających budynki uniwersyteckie. Zdjęcie to, odpowiednio powiększone i oprawione, zostało wręczone Profesorowi podczas uroczystości jubileuszowych w siedzibie Towarzystwa w 2005 r. Warto dodać, że zdjęcie to zostało ostatnio wystawione przez małżonkę Profesora, Panią Profesor Bożennę Wyrozumską, na aukcji charytatywnej Wielkiej Orkiestry Świątecznej Pomocy. Profesor Wyrozumski zaangażował się także w obronę Polskiej Akademii Umiejętności, w której od 1994 r. pełnił funkcję sekretarza generalnego. Gdy w 2002 r. Anna Rybicka opublikowała książkę na temat Instytutu Niemieckiej Pracy Wschodniej w Krakowie, w której sugerowała kolaborację z okupantem niektórych profesorów krakowskich, Jerzy Wyrozumski wraz z żoną wydali drukiem niepublikowany rękopis Stanisława Kutrzeby, $W$ obronie spotwarzonej instytucji, stanowiący obronę Akademii przed zarzutami ówczesnej prasy.

Profesor Jerzy Wyrozumski zwykł mawiać o sobie, że jest krakowianinem z wyboru. W wywiadzie udzielonym Andrzejowi M. Kobosowi w 2007 r. szczerze wyznał, że zaraz po przyjeździe do Krakowa „nie miał większych powodów, aby Kraków kochać”'. Po kilkudziesięciu latach stosunek Profesora Wyrozumskiego do Krakowa stał się emocjonalny i jak sam przyznał w owym wywiadzie, teraz może spokojnie powiedzieć, że „kocham Kraków i bardzo identyfikuję się z Krakowem". Miasto zaś, za wszystko co Profesor zrobił dla niego, odwdzięczyło się nadaniem Mu medalu Cracoviae merenti.

Profesor Jerzy Wyrozumski animował życie naukowe w Polsce. Pełnił wiele ważnych funkcji, z których warto tutaj wymienić następujące: członek czynny Polskiej Akademii Umiejętności i jej sekretarz generalny (1994-2015), wspomniany już wcześniej prezes

${ }^{1}$ Zob. Jerzy Lesław Wyrozumski i Andrzej M. Kobos, Respekt dla źródła historycznego, [w:] Po drogach uczonych, t. 2, Kraków 2007, s. 603-627. 
Towarzystwa Miłośników Historii i Zabytków Krakowa (1980-2015), przewodniczący Rady Fundacji Promocji Kultury Krakowa, przewodniczący Rady Muzealnej Państwowych Zbiorów Sztuki na Wawelu, kierownik Ośrodka Badań Międzynarodowego Centrum Kultury w Krakowie oraz członek Centralnej Komisji do spraw Stopni i Tytułów. Za swoją działalność naukową i społeczną odznaczony wieloma orderami i medalami: Krzyżem Komandorskim św. Sylwestra, Krzyżem Komandorskim Orderu Odrodzenia Polski, Krzyżem Oficerskim Orderu Węgierskiego, estońskim Orderem Krzyża Ziemi Maryjnej. Wielkie naukowe dzieło Profesora Jerzego Wyrozumskiego zostało także docenione przez polskie i zagraniczne uniwersytety, które nadały Mu tytuł doktora honoris causa. Ostatniego wyróżnienia (doktoratu Uniwersytetu Jana Kochanowskiego w Kielcach) nie zdołał już jednak odebrać za życia. Zostało ono przekazane Rodzinie Profesora podczas uroczystości pogrzebowych w krakowskim kościele św. Anny.

Prochy Profesora Wyrozumskiego zostały pochowane 9 listopada 2018 r. w Alei Zasłużonych na cmentarzu Rakowickim. Droga życiowa Profesora Jerzego Wyrozumskiego to wspaniały przykład wielkiego Uczonego, obdarzonego niezwykłą skromnością i uczciwością, na którego pomoc można było zawsze liczyć. 